\title{
Concubinage in Seventeenth-Century Chinese Literature: A Historical Study of Xing-shi yin-yuan zhuan Yifeng Zhao
}

ABSTRACT: This study explores the subte patterns, variety, and changes in Chinese concubinage during the seventeenth century by focusing on cases described in Xing-shi yin-yuan zhuan, a seventeenthcentury Chinese novel, and other literary and historical sources. It argues that the various social practices of concubinage in late Ming China diverged from government regulations. Chinese concubinage underwent remarkable changes by the seventeenth century in comparison with earlier periods. Even as concubinage was widely accepted, certain Confucian intellectuals of this period criticized the institution.

Married women in late imperial China could generally be put into two categories, $q i$ and qie. A gi (wife) was a man's major legal spouse. Besides one qi, a man might have one or even more than a dozen qie (concubines). ${ }^{1}$ As Patricia Ebrey asserts in her study of Song (AD 960-1279) concubinage, concubines were recognized sexual partners of a man, expected to bear children by him, and to have marginal kinship status in his family. Her study convincingly distinguishes concubines from wives in terms of law, ritual, and social status. In Song China, she argues, "concubines fell more to the side of the maids than to that of wives." According to Ebrey, most of the features of Song concubinage were present in later periods of Chinese history until the eighteenth century, when the social status of concubines was elevated as a result of a promotion of the bondservants' status. ${ }^{2}$ There are, however, few detailed studies of Chinese concubinage before the eighteenth century. According Chen Guyuan, a Chinese scholar of marital history, concubinage was actually not popular during the Ming (AD 1368-1644) period because of the government's rigorous rules limiting the conditions under which concubines could be taken. It was in the Qing ( $A D$ 
1644-1911) dynasty that concubines became popular under a laissez-faire government policy that paved the way for the development of modern Chinese concubinage in the nineteenth and early twentieth century. ${ }^{3}$

It is apparent, however, that the Ming government's attempt to restrict the taking of concubines had been crippled no later than the seventeenth century, and that concubine taking had become a very common practice before the consolidation of the early Qing empire. Thus, there were important inconsistencies between government regulations and social practices in regard to concubinage in late Ming China. Furthermore, an examination of some previously unexamined subtle patterns of Chinese concubinage reveals remarkable variety. In the seventeenth century, for example, concubines were al ready challenging wives although bondservanthood remained a solid social institution. The intellectual discussion of concubinage in the seventeenth century also leads us to an understanding of the variety within this social institution.

A major obstacle to an understanding of the diverse characteristics of Chinese concubinage during the seventeenth century is that the main body of historical sources, official histories and even local gazetteers of that time, does not provide sufficient detail. Researchers in this field, then, have to collect historical information from other sources. In this regard, seventeenth-century Chinese fiction, especially Xing-shi yin-yuan zhuan (A Marriage Story to Awaken the World) deserves careful attention. ${ }^{4}$ This novel, of about a million Chinese characters, was written in the late seventeenth century by a Shandong author pseudonymously named Xizhou Sheng. ${ }^{5}$ The immense value of this work for historical studies impressed even the pioneer of the Chinese New Cultural Movement and a leading historian, $\mathrm{Hu} \mathrm{Shi,} \mathrm{as} \mathrm{early} \mathrm{as} \mathrm{sixty} \mathrm{years} \mathrm{ago.} \mathrm{Hu}$ asserted, "In terms of history, this novel is a most substantial and detailed documentation for cultural history." He predicted that researchers of aspects of seventeenth-century Chinese social customs, education, economic history (such as grain prices, famines, and costs of purchasing official 
titles), political corruption, and social miseries, all would need to study this work. ${ }^{6}$ Recently, literary historian Andrew H. Plaks, described this novel as a work with "a thoroughgoing realism that is almost cinematographic in detail." Yet, historians have paid much less serious attention to Xing-shi than literary researchers have.

In using fiction like Xing-shi to do historical research, the scholar faces a problem of extracting valid historical evidence from fiction. This study uses five methodological assumptions to deal with this problem. First, it is assumed that in seventeenth-century Chinese literature real ist fiction reflects history more directly than purely escapist fiction. In the popularly used categories of seventeenth-century Chinese novels, the so-called xing-shi xiao-shuo (novels to awaken the world) are generally considered more historical than yan-ging xiao-shuo (romantic stories). Secondly, description about details of lifestyles-speech patterns, everyday items, everyday life, and general family relations may be closer to reality than dramatic plots. Thirdly, within a particular work of fiction, sections that are peripheral to the main story may reflect historical facts more accurately. In Xing-shi, for example, the major story of a reincarnated shrewish wife is purposely and clearly distorted to attract readers; however, the social milieu described in the novel better fits other historical materials. Andrew H. Plaks, observes that Xing-shi "distributes several chapters which leave both narrative lines behind and present chains of anecdotes with only loose thematic links to the main story." 8 Based mainly on such a relatively independent section of Xing-shi, Glen Dudbridge wrote a magnificent study on the social organization of Taishan pilgrimage in seventeenth-century China. ${ }^{9}$ Fourthly, the author's comments, which appear in Xing-shi frequently, are historical, reflecting opinions of a contemporary author. Finally, since fiction reflects history but can hardly be viewed as a representation of actual events, evidence must be drawn from other sources to enhance analysis.

The main plot of Xing-shi has two parts. In the first part, Chao Yuan, a son of a new middle class gentry family of 
Shandong becomes estranged from his wife, Woman Ji, and takes an actress-prostitute, Shi Zhenge, as his concubine. While hunting, Chao Yuan kills a fox. Wornan $\mathrm{Ji}$, upset by her husband's actions and the concubine's insult to her, commits suicide. Soon afterwards, Chao Yuan is killed by a cobbler because Chao has been carrying on an affair with the cobbler's wife. The clan of Chao, taking advantage of the fact that the Chao family lacks a male descendant at that moment, asks for a redistribution of the properties of the Chao family. Fortunately, a concubine of Chao Yuan's father soon gives birth to a posthumous son of the old Chao, and the Chao household is able to remain intact. The second part of the Xing-shi story unfolds in Mingshui, a small town of Shandong. Di Xichen, the reincarnated Chao Yuan, is now a shengyuan (xiucai, the primary level degree holder in the civil service examination system) and a son of a rich peasant and hotel owner. Di Xichen suffers constant and serious abuse from his wife Xue Sujie, who is the reincarnated fox killed by Chao Yuan coming to take revenge. To escape from his shrewish wife, Xichen marries Tong Jijie, who is the incarnation of Chao Yuan's wife, Woman Ji, as his concubine in Beijing. In terms of ferociousness, Jijie turns out to be second only to Sujie. Later, when Sujie and Jijie confront each other, they fight but eventually make concessions to each other. The story ends with Sujie's death as a punishment of the Buddha to the furious wives. Thus, there are five concubines in Xing-shi whose stories are described in detail, namely, Shen Chunying, Shi Zhenge, Tiaogeng, Woman Long, and Tong Jijie.

The present study uses evidence provided by Xing-shi, supplemented by Wen-ji (collections of private works), Bi$j i$ (private notebooks), and official histories, to examine how concubinage as a social institution and an aspect of culture functioned in society. These sources shed light on the reasons or excuses men gave for taking concubines; how and from where concubines came to their husbands' households; the social status of these concubines and their rights to property in their husbands' households, the respect 
they received, and their legal status; as well as attitudes of some seventeenth-century Chinese intellectuals towards concubinage. The major cases discussed in this paper reflect situations in the Shandong area.

The main reason men took concubines in traditional China was to produce male progeny. Officially, the privilege of taking concubines was related to a man's social class and age. The ancient standard summarized by the late Han (AD 25-220) scholar Cai Yong was that a ging or da-fu (senior official) could have a wife and two concubines, while shi (ordinary officials) could have a wife and one concubine. ${ }^{10}$ Commoners were not traditionally expected to have concubines." The law of Ming stipulated that "A min (commoner) can have concubines only when he is at least forty years of age and without a son. Offenders of this regulation are subject to forty strokes." 12 Cases given in Xing-shi show, however, that in social practice, neither official ideology nor the laws were seriously followed: major limitations to the taking of concubines were the financial circumstances of households and the need to maintain family harmony.

In Xing-shi, Xue Zhen's taking of a concubine illustrates orthodox practice. The wife of this retired educational official has never given birth. So when Xue is 52 , he marries Woman Long in the hope of begetting a son. Later, Woman Long gives birth to a girl and three boys. As would be expected, Woman Long's status in this family falls between that of the wife and the maids. ${ }^{13}$

Other cases in the story, however, show that reality could differ from official strictures. Chao Sixiao, a retired semi-prefectural administrator in Xing-shi, takes a young maid as his concubine but first tries to obtain his wife's consent.

Old Chao said: "When I was a xiucai, I was preoccupied with studying for a higher degree. Later, as an official, I kept myself busy and it was even easier to kill time. But now I am home without anything to do. I can't even spend my time in teaching a son or grandson. I have to get a person to attend to 
me day and night. Such a person is also needed for looking after my clothes." Madame Chao then generously agreed. ${ }^{14}$

According to Cai Yong's standard and the law of the Ming, Chao Sixiao's gentry status makes him eligible to have a concubine. Nevertheless, as he already has a married son, he cannot use his desire for male descendants to justify raking a concubine. Instead, he uses killing time during retirement and obtaining better service as excuses and manages to avoid mentioning sex when he discusses this matter with his wife. It is likely that Chao Sixiao's story reflects the social reality of his time.

The case of Chao Yuan, Chao Sixiao's son, is also instructive. Chao Yuan can marry a wife only with the financial help of his father-in-law as Chao Sixiao is an impoverished private teacher. He therefore treats his wife like a goddess. One year after the marriage, Chao Sixiao is appointed county head and thus Chao Yuan finds himself suddenly rich. This young man immediately starts to acquire concubines. He first shou-yong (sexually takes) a maid but gives her up only two days later. After that, Chao Yuan takes a daughter of a military commander as his concubine, whom he also abandons because she fails to please him. Then Chao Yuan takes Shi Zhenge, an actressprostiture, as his concubine and indulges in sexual activities with her. He rejects his wife totally. ${ }^{\text {is }}$ Although his father is an official, since official positions in the Ming bureaucracy are nor hereditary, Chao Yuan is merely a commoner. Based on the law of the Ming, a commoner under forty, like Chao Yuan, was not eligible to take concubines. Since the author of Xing-shi, however, did not describe Chao Yuan's taking concubines as an extraordinary story, apparently, the law was not in force in seventeenth-century China and concubinage was common among rich commoners, a point which will be discussed later.

In Xing-shi, Di Binliang, a sixty-three-year-old rich peasant and small hotel owner with a married son, also takes a concubine. This marriage is suggested by Madame Tong, a capable woman of an artisan-merchant family in 
Beijing. Madame Tong advises that when Di Binliang needs to hire a cook, it would be a better idea to buy a woman-cook called a quan-zao (full-duty woman-cook) than to hire a professional cook who would require a salary. "Full- dury" here means serving as both cook and sexual partner of the master, or alternatively being given to a servant in the master's household. It is after demonstrating excellent skills in cooking that Tiaogeng, an unattractive eighteen-year-old girl becomes a cook-concubine of $\mathrm{Di}$ Binliang. ${ }^{16}$ In this case, improving household maintenance is the primary reason for Di Binliang's taking Tiaogeng. It seems, then, that it may not have been uncommon in seventeenth-century China to combine sexual and utilitarian considerations in rationalizing the acquisition of concubines.

Men may also have taken concubines to satisfy a desire for intimate relations with a woman after their relationship with their wives had broken down but, for one reason or another, their marriages could not be formally ended. $\mathrm{Di}$ Xichen, the son of Di Binliang in Xing-shi, suffers physical humiliation from his wife. When he goes to Beijing to study, he is attracted by the amiable character of a Beijing girl, namely Jijie, and he marries her. Since Di Xichen has decided to establish a new family, the familial position of Jijie is higher than that of concubines previously discussed. An informal title is available for Jijie: liang-tou-da (another mistress separated from the first wife). Jijie acts as if she were the true mistress in this new household. ${ }^{17}$ A similar case is described in a story told by Xue Zhen when he is giving his daughter advice on the eve of her wedding. ${ }^{18}$ Liang-tou-da as actual secondary wives appear in other works of the seventeenth century, for example, in Cu hu-lu written by Fuci Jiaozhu, and in Ling Mengchu's short stories. ${ }^{19}$ These examples from different sources indicate that the liang-tou-da status could reflect an oral promise or a practical personal treatment that evaded the restrictions of the one-legal-wife policy of seventeenth-century China.

Xing-shi shows that concubines in seventeenth-century China were procured as they had been in the past, from 
the ranks of maids and prostitutes, and from ordinary families. Maids, the most convenient source of concubines, either could be purchased in the market or could be the daughters of one's household servants. Because female bondservants could be sexually used by their masters without giving them any formal titles, to Chunying, a maid in Xing-shi, becoming a formal concubine meant a promotion in terms of family status. In this case, taking concubines would seemingly cost the masters little. To get prostitutes as concubines, the masters needed to pay to the owners of the prostitutes the body price, which ranged widely. Prostitutes could obtain liang (fine) status through marriage. Girls from ordinary families might be interested in becoming a rich man's concubine to enhance their material security. ${ }^{20}$ In such cases, there were usually negotiations concerning the position of the concubine in her future husband's family before the marriage. Concubinage was thus a far more commercial social institution than formal marriage. The expenditures made for taking concubines, including market prices, a betrothal gift if any, and expense for the wedding ceremony were important aspects of concubinage. While conventional historical sources provide us with little information in this regard, Xing-shi provides a more complete picture.

The monetary value of concubines largely depended on their background. In Xing-shi, Jijie, a virgin from a fine family, marries Di Xichen. Madame Tong, Jijie's realistic and considerate mother, does not want to profit financially from marrying her daughter off. She takes only twenty taels of silver from $\mathrm{Di}$ Xichen as a betrothal gift, although Di Xichen would have been glad to have given her more. Following Madame Tong's instructions, Di Xichen also has some good jewellery and new clothes made for Jijie. The wedding ceremony is a simple one, yet reasonably formal. ${ }^{21}$

Zhenge is the most expensive concubine in Xing-shi. The price paid to the old master of this actress-prostitute is eight-hundred taels of silver, an astonishing price for Chao Yuan to pay. The training expenses for this actress and her 
key position in that performing group are all factors which make her price that high. Furthermore, since Chao Yuan's wife, Woman Ji, cannot get along with the newcomer, another house, instead of a room, is arranged for Zhenge; some servants and maids are bought accordingly. New clothes and jewellery for this favourite concubine are also mentioned. ${ }^{22}$ A tenant woman in one of Chao's farm houses, asks, "What kind of a person can cost so much? With eight-hundred taels of silver, you could have made a person out of solid, sterling silver!"23

In contrast, Chunying costs little. Chao's family buys this girl when she is eleven years old for only five taels of silver. When she marries her master, her parents are given twelve taels of silver as an additional betrothal gift. There is no wedding ceremony or official registration necessary for such an event. In addition to the new clothes and some personal ornaments, a furnished personal room is all that is considered necessary for this humble bride. ${ }^{24}$

The negotiation process for the purchase of Tiaogeng provide remarkable insight into the Beijing concubine market in the seventeenth century. During the negotiations, the brokers begin by asking for thirty taels, the top price on the market, and then reduce their price to twenty-seven taels. Madame Tong argues that while Tiaogeng can be considered an excellent cook, she is neither good looking, nor a virgin. ${ }^{25}$ Furthermore, according to Madame Tong, an unattractive cooking girl who could make everyday meals but not a family banquet, is usually sold for ten to thirteen taels in the Beijing market, whether or not she is going to be a concubine. She consequently strikes the deal at twenty-four taels. Another tael covers the fees for two marriage brokers. The gifts given to Tiaogeng when she is bought in Beijing are merely some new clothes, a suit of second hand pu-chen (things to put on the bed, usually a mattress, a comforter, and a pillow), a pair of black silver earrings, and four black silver rings. ${ }^{26}$ Back home in Shandong, a room, a set of new pu-chen, a new silk coat and a pair of trousers, and a new red jacket are all the arrangements made for her. No wedding is arranged. ${ }^{27}$ For 
purposes of comparison, the following chart shows the prices of other merchandise mentioned in Xing-shi. ${ }^{28}$

Chart 1: Cost of Merchandise Mentioned in Xing-shi

merchandise

cost in taels of silver

source

a suit of official gown

a pair of good shoes

one bench fur of marten

one dan of millet

one dan of good rice

$16-17$

0.7

p. 298-9

36

p. 7

p. 7

5

p. 259

2

p. 540

The late Ming scholars, Shen Defu and Zhang Dai, also mention the concubine markets in Beijing and Yangzhou. According to Zhang Dai, many farnilies in Yangzhou prepared young girls to be concubines. Those girls were named shou-ma (lean horses). Hundreds of brokers made a living in this "lean horse" business. ${ }^{29}$

Generally speaking, concubines in the Ming and Qing periods continued to be subject to their husbands and the main wives' domination as they were in the Song period. In Da Ming lu (The Law of the Great Ming), concubine and husband were addressed as "concubine and her master," while wife and husband were addressed as "wife and her husband." The mourning obligations of wives and concubines upon the death of their husbands were the same. Concubines, however, were required to mourn for wives while wives were not obligated to mourn for concubines. ${ }^{30}$

Ming criminal law suggests that the status of concubines was higher than in the previous Song Dynasty. In the official legal documents of the Ming, wife and concubine were usually listed together like "gi-qie" (wife and concubine), and though subject to the same laws, the penalty for the same offense might differ. For example, the punishments for a wife or concubine who deliberately murdered her husband, beat her husband to death, or verbally abused a parent or grandparent of her husband were all the same. If a concubine beat a wife resulting in an 
incurable injury, she would meet the death sentence; in the reverse instance, a wife would not face the death penalty. ${ }^{31}$

The way people addressed each other in Xing-shi, reflects the subordinate status of concubines in Shandong in the seventeenth century. Because human purchase was usually made in the name of adoption, servants in the Shandong area usually called their master die (father), and their mistress niang (mother). Concubines usually came into their husbands' household in the same way. They, therefore, were expected to address other people in the household as the servants did. Although this manner of speech mainly functioned to distinguish social status rather than generational order, concubines were still supposed to treat their husband and the first wife like their parents-with filial piety.

In Xing-shi, Jijie is the only concubine who does not call her husband "father." This may be because she holds a marginal status (liang-tou-da), she is from Beijing, and she never lives in the Shandong area, even after marriage. When Jijie confronts the first wife of Di Xichen in Sichuan, she physically fights with the wife and then reaches an oral agreement with the wife that the concubine will address the wife as jie (elder sister). ${ }^{32}$

The servants of the $\mathrm{Di}, \mathrm{Chao}$, and Xue families call the first wives of the masters niang, while they call the concubines of the masters yi (aunt). Concubine Tiaogeng calls her husband's son Di Xichen shu (uncle), which is exactly the same way the servants address Di Xichen. Interestingly, the children of concubines do not call their biological mothers niang, but rather jie! The son of concubine Chunying calls her Shenjie (Sister Shen, Shen being her maiden surname); he uses the term "mother" for his father's legal wife. ${ }^{33}$ Chart 2 shows how people in the left column address people who are listed in the top row. ${ }^{34}$ 
Chart 2: Modes of Address Based on Kinship and Status

\begin{tabular}{l|l|l|l|l|l|l}
\hline $\begin{array}{l}\text { master or } \\
\text { relation to } \\
\text { the master }\end{array}$ & master & wife & son & daughter & concubine & $\begin{array}{r}\text { servant } \\
\text { and } \\
\text { maids }\end{array}$ \\
\hline master & n.a. & $?$ & name & name & name & name \\
\hline wife & $?$ & n.a. & name & name & name & name \\
\hline son & father & mother & brother & sister & sister & name \\
\hline daughter & facher & mother & brother & sister & sister & name \\
\hline concubine & facher & mother & uncle & aunt & sister & name \\
\hline $\begin{array}{l}\text { servants and } \\
\text { maids }\end{array}$ & father & mother & uncle & aunt & aunt & name \\
\hline
\end{tabular}

It is highly probable that the different modes of address evident in Xing-shi reflect the actual social status and social relations among the speakers in the Shandong area in the seventeenth century. These patterns indicate that the status of a concubine was slightly higher than that of servants and maids, but slightly lower than the children of the master.

To help ascertain the status of a concubine in her master's household, the scholar might also wish to consider the value of her dowry. Watson and Ebrey find the dowry crucial for understanding traditional Chinese marriages. ${ }^{35}$ It is, however, much less important in understanding concubinage than marriage in seventeenth-century China. This is because most concubines were not actually married but were purchased from their former owners or parents, who were looking for financial reward. Under these circumstances, there was very little dowry available for these impoverished girls; furthermore, they had few assets of their own. Exceptions may be found among concubines who had been widows or prostitutes, since they might have saved up private property before becoming concubines. Among the concubines in the story of Xing-shi, only Jijie, who comes from an ordinary family and obtained a liang- 
tou-da status, comes with a dowry. Xing-shi suggests that the position of a concubine in her master's household mainly depended on her character, her origin, appearance, performance as her husband's sexual partner, ability and effect in child bearing and household work, her children's position in the household, and her personal relationships with other members in that household.

In Xing-shi, Chunying's case suggests that a concubine might be promoted to be a mistress because of her contribution to the family, despite her humble origins. This concubine is taken under the careful protection of the legal wife because she produces a son for the Chao family soon after the only two males have died. Chunying's son secures the property and continuity of the Chao family. Moreover, Chunying chooses to stay as a widow in the Chao family and rejects her parents' suggestion to remarry. In her later years, Chunying is addressed as ernai-nai (the second mistress). ${ }^{36}$ Historical records contain similar cases. Qian Qianyi, a Minister of Rites in late Ming China, once drafted an edict for the emperor which granted an official's biological mother, a concubine, an honourable title, namely, An-ren. Previously, this was a title reserved exclusively for the legal wives of outstanding officials. In the edict, Qian justified this unusual promotion of concubines by claiming that for the first time in history the first emperor of the Ming dynasty had decreed that sons should mourn their biological mothers, even if they were concubines. ${ }^{37}$ This practice and the story of Chunying together indicate the possibility of concubines being treated like legal wives, both institutionally and in practice.

Other examples from the story also suggest how a concubine's status depended on various factors apart from the dowery. Concubine Zhenge, the most expensive concubine in Xing-shi, is not much respected by other members of the Chao family, not only because she has been a prostitute, but also because she squeezes out the legal wife, leading to the death of the wife and a timeconsuming lawsuit. Moreover, the mother of her husbandmaster dislikes Zhenge's licentious character. ${ }^{38}$ 
Woman Long's misfortune seemingly comes when she speaks out in favour of her daughter Sujie. For example, in one incident, Sujie physically abuses her husband and verbally offends her mother-in-law and Xue Zhen himself, he then retaliates by beating up Woman Long. ${ }^{39}$ Later, when the old-fashioned education officer, who believes that young women should avoid appearing in public, criticizes Sujie for attending a temple fastival, Woman Long defends her daughter. ${ }^{40}$ Although Madame Xue never beats Woman Long, neither does she respect her. When woman Long wants to go to the $\mathrm{Di}$ house to visit Sujie, who is ill, Madame Xue says "A concubine to visit the in-law's home? If you don't care about being unwelcome, you go. I would not stop you." Woman Long complains in a low voice: "Why? Do the wives have horns on their heads and scales on their bodies? Concubines have exactly the same genitals as wives do. Why always say concubines this and concubines that ...." ${ }^{41}$ In the end, she dares not go. Even Woman Long's two elder sons give more respect to Madam Xue than they do to their own mother. Many times, they firmly reject Woman Long's instructions. ${ }^{42}$ Woman Long's humiliation ends only after the death of Xue Zhen and Madame Xue. This story suggests that concubines should not visit their in-laws (at least not alone). Her story more broadly hints at the abuse concubines might face if they did not observe unwritten conventions that assigned them a passive role in the household.

Concubines might be treated well if they behaved exactly as expected. Tiaogeng is such a case in Xing-shi. She knows that her position as a cook-concubine requires her to work very hard without complaining or making unseemly demands. She also gives birth to a son for the Di family. When her husband-master Di Binliang dies, she shares a good part of the property from the Di family in the name of her son, although some contradictions occur. Because of the property settlement, Tiaogeng remains the widow of her husband for the rest of her life.

The marginal status of liang-tou-da formed a challenge to the traditional wife domination of concubines in 
seventeenth-century China. In Xing-shi, Jijie as a liang-touda, enjoys a wife's life. Corroberating this is the case of a local official in the late Ming period who dealt with a concubine whose status was similar to that of a liang-touda. In that case, a man who already had a wife, took a widow as his concubine in the hope of having a son by her. He called her wai-fu (outside wife). She was his sexual partnership for ten years, until his death. What is of note is that this woman never considered moving into the man's principal household to live alongside the legal wife. Furthermore, when the husband died, the legal wife and the wai-fu sued one other. ${ }^{43}$ Researchers into late Ming government records have found no legal recognition of this sort of marginal status. This example, therefore, suggests that social practice in late Ming concubinage was at variance with government regulations. This practice might have led to an institutional change in the eighteenth century, when the Qing government allowed men to be appointed heir to their uncles as well as to their fathers. Such men then could marry two women in the names of the two family branches. One woman was recognized as the legal wife; another woman married to the same man might be named ping-gi (equal wife). Historian Chen Guyuan suggests that ping-gi was also named liang-tou-da. ${ }^{44}$ The position of a liang-tou-da was virtually closer to a wife than to a concubine.

Even an ordinary concubine might challenge the wife's position of dominance. In Xing-shi, concubine Zhenge successfully squeezes out the legal wife, relying on the husband's fondness of her. A similar case is mentioned in an early Qing notebook. Military man, $\mathrm{Li}$, joined the Qing expedition to Fujian area in 1673. When he came back to Beijing, he married a concubine. "Believing that the concubine might not like to see his wife, Li rejected his wife and divorced her." This wife then had to spend the rest of her life like a widow. ${ }^{45}$ Based on the law of Qing China, in fact, $\mathrm{Li}$ needed a better reason to divorce his legal wife. Nevertheless, neither the wife nor her son even thought about resolving this family problem by taking the 
case to court. The point is that a concubine could actually replace the position of a wife by having the support of her husband. It might have been common practice to treat concubines like wives in seventeenth-century China. A concerned thinker of that time, Tang Zhen (AD 16301704), once wrote, "To treat a concubine like a wife leads to serious danger; to love the beauty of a concubine then listen to her is a smaller danger." 46 These kinds of challenges all required the husbands' support.

Scholars who investigate seventeenth-century Chinese concubinage are confronted by social diversity, and it is difficult to determine the philosophical, religious, or cultural mentalities underlying these activities. In fact, this social diversity is paralled in the intellectual reflections of the time on concubinage.

On the one hand, concubinage had been equally common among the intellectual gentry as it was among middle class families, a situation well described in Xing-shi and contemporary records. Feng Qizhen, who lived in the late Ming period, was said to have had many concubines. ${ }^{47}$ When a former county head, who was an uncle of the well-known writer Zhang Dai, was dying, concubines who surrounded his bed were described as many as "woods." 48 Gu Yanwu (aD 1613-1682), one of the bestknown Confucian scholars and dissidents in the Qing, had at least three concubines during his life. ${ }^{49}$

On the other hand, intellectuals were not positively inclined towards concubinage. Seemingly, at a deeper level of traditional thinking, concubinage still implied an imperfection of married life. An early Qing scholar Chu Renhuo, recounted the royal wedding of Emperor Wanli (AD 1573-1619) of the Ming dynasty. Presiding over the royal ceremony, "following the tradition," was a couple who had children but who had previously never been married to anyone else and who never had a concubine. ${ }^{30}$ Niu Xiu, another early Qing scholar gave another example. A talented student named Hang Yunmen from Henan province was engaged to a girl who later became blind. His future father-in-law therefore sent a concubine with the 
bride to him as compensation. Han rejected the concubine and said: "I would rather not see that concubine, so that my wife and I can enjoy our happiness." For this reason, people who knew Han appraised him as an honest and sincere person. ${ }^{51}$ Chu Renhuo also recorded a poem entitled "Mai-qie xing" (On Concubine Purchase), in which the author criticized those new jinshi (presented scholars, the highest degree holders in Civil Service Examinations) for taking concubines and forgetting their poorly dressed wives at home who were sewing winter clothes for their husbands. ${ }^{52} \mathrm{Gu}$ Yanwu's thoughts on his own concubinetaking and his advice to friends are even more noteworthy. In around 1674, Gu Yanwu wrote to his close friend, Wang Hongzhuan, to advise him not to take a concubine. Gu began by quoting the pronouncement of Western Han Confucian scholar, Dong Zhongshu (BC 197-104), that gentlemen should not indulge in sex. A period of abstinence for ten days was suggested for a young and strong man, twenty days for a middle-aged man, and forty days for an early senior. Gu wrote that when he was fifty-nine, he had not had a son yet. Then, he "bought" a concubine. A year or so later, he started to suffer from many diseases, which he attributed to having a concubine. He then adopted his nephew to be his heir and married off the concubine. To make his argument more convincing, $\mathrm{Gu}$ gave another example in the same letter: Yang Zichang, his lifelong friend, "bought" two concubines when he was over sixty. In three to five years, the already weak-visioned Yang lost his vision completely and furthermore, the boy produced by one of Yang's concubines died at an early age. According to $\mathrm{Gu}$, as for those who already had sons, grandsons, and even great grandsons but took concubines, such men were courting disaster. He then warned Wang Hongzhuan not to take concubines since Wang was fiftynine years old, had a vision problem, and already had great grandsons. ${ }^{33}$

According to Gu Yanwu, for reasons of health, Confucian doctrines discouraged the taking of concubines, even for older men who lacked male heirs. The author of Xing-shi, 
Xizhou Sheng, concurs with Gu Yanwu in this regard. He describes Chao Sixiao's taking of Chunying as an "excessive idea," for which he pays with his life fifty days later. ${ }^{54}$

$\mathrm{Cu}$ bu-lu, a late Ming novel, presents a very different attitude to that of $\mathrm{Gu}$ Yanwu. This book portrays concubinage as absolutely necessary for husbands who wanted male progeny, and as beneficial to wives as well. Cheng Gui, a sixty-four year old male character in this novel enjoys satisfactory intercourse with his concubine without ill effects. ${ }^{5 s}$

Concubinage in seventeenth-century China was similar to concubinage in earlier periods. Nevertheless, there was considerable variety in concubinage. Although the law of Ming China restricted the conditions for taking concubines, concubines were common in wealthy families. Also, contrary to the law forbidding the sale and purchase of human beings, there were thriving concubine markets in both north and southeast China. When state policies and ideology were too weak to regulate social activities in this regard, men usually needed to provide reasonable excuses to their wives for taking concubines if they were to avoid serious family conflicts, especially berween wives and concubines. The desire to have male progeny was considered an acceptable reason for acquiring concubines, but other excuses included household maintenance, personal service, or sexual pleasure.

Concubines could be maids who had grown up in the same household, prostitutes, girls for sale on human markets (including those specially trained with particular skills to be concubines), and daughters of ordinary families who wanted to marry into wealthy families. The majority of concubines were bought by their husband-masters, although some did undergo semi-standard marriage procedures. The commodity value of a candidate as concubine was estimated against her original social status, comeliness, fertility, virginity, skill as entertainer, training in housework, and personal virtue. According to these factors, the market prices of ordinary concubines usually ranged from about ten taels to thirty taels. Under some 
extraordinary circumstances, the price of a concubine could reach to several hundred taels of silver or more.

The common status of concubines was usually higher or close to that of maids; according to criminal law, concubines were considered to be almost on a par with or slightly below that of wives. The actual position of a particular concubine within a household also depended upon her contribution to the family; her relationship with her husband, the legal wife, and other family members. The children of a concubine considered the legal wife as their mother, but accorded their biological mothers less respect. Physical and verbal abuse of concubines was common.

Quan-zao and liang-tou-da are two variants found in seventeenth-century Chinese concubinage. The existence of quan-zao concubinage awaits further study. Evidence suggests, however, that a man might take a concubine mainly for household maintenance, rather than for child bearing or sexual pleasure. This possibility also suggests that bondservants and concubines might have been more closely linked during that period. The confirmed existence of liang-tou-da, on the other hand, sheds light on the ability of concubines to challenge the positions of legal wives. Concubines might virtually replace legal wives in everyday life with their husbands' support. The late Ming government started to recognize the improved status of concubines by granting the concubine mothers of distinguished officials honourable titles. With some exceptions, however, the leading Confucian ideology during seventeenth-century China did not generally approve of concubinage.

\section{NOTES}

"I would like to thank those who assisted me in helping me to prepare this article: my PhD adviser, Dr. Brian Evans, Mr. Eric Gormley, the anonymous referees and the editors of Past Imperfect.

'With slight differences, gie, ce-shi, fu-shi, wai-shi, xiao-xing, xiao-loopo, and ru-fu-ren are all Chinese synonyms for the English word "concubine." While gie is the most commonly used synonym for concubine, ce-shi literally means "side wife"; fu-shi literally means 
"vice-wife"; a wai-shi was a "concubine" who lived outside the principal houschold; xiao-xing (litele star) is a term from ancient classic Shijing, which became a popular synonym for concubine in seventeenth-century Chinese literature; xiao-lao-po (small wife), is popularly used in oral language to mean "concubine"; ru-fu-ren is a honorific title to address other people's concubines. In the late Qing and Republican periods, yi-tai-tai (aunt mistress) was another popular term for "concubine." Beyond these, liang-tou-da is a name given to concubines who lived separately from the principal wives and held actual status of mistress in their households. See the following parts of this paper. Qie has meant "concubine" since the Western Jin period (AD 265-316). See Qu Xuanying, Zhongguo she-hui shi-liao cong-chao (Shanghai: Shanghai Shudian, 1985), 591. According to Qing historian. Zhao Yi, the term ce-shi referred to sons other than the legal wife's eldest son. It had been used as a synonym for "concubine" since the third century. Other old synonyms for "concubine" which had become unpopular in early Qing China are xiao-qi, bang-qi, xia-qi, shao-qi, and shu-gi. See Zhao Yi, Gai-yu cong-kao (eighteenth century, rpt., Shanghai, Shangwu, 1957), 790-5.

2Patricia Ebrey, "Concubines in Sung China," Joumal of Family History 11 (1986): 1-24.

${ }^{3}$ Chen Guyuan, Zhongguo hun-yin shi (Shanghai: Shanghai Shudian, 1936), 68-9. For studies on modern Chinese concubinage, refer to Maria Jaschok, Concubines and Bondservants: A Social History (London: Zed Books, 1989).

There are several editions of Xing-shi yin-yuan zhuan. Quotations in this paper are from Xizhou Sheng, Xing-shi yinguan zhwan, (seventeenth century, rpt., Taipei: Shijie Shuju, 1961). Yenna Wu has translated the title of this novel as Marriage Destinies to Awaken the World.

sFor a brief yet careful introduction to the controversy in determining the authorship of Xing-shi, see Glen Dudbridge, "A Pilgrimage in Seventeenth-Century Fiction: T'ai-shan and the Hsing-shih yin-yuan chuan," T'oung Pao 77 (1991): 226-52. For a more comprehensive study, see Yenna Wu, "Marriage Destinies to Awaken the World: A Literary Study of Xingshi yinyuan zhuan," (PhD diss., Harvard University, 1986).

${ }^{6} \mathrm{Hu}$ Shi, "Xing-shi yin-yuan zhuan Kao-zheng," Hu Shizuo-pin ji, vol. 17, (Taipei: Yuanliu, 1988), 71.

7Andrew H. Plaks, "After the Fall: Hsing-shih yin-yuan zhuan and the seventeenth-century Chinese novel," Harvard Joumal of Asiatic Studies 45 (1985): 543-80.

IJbid., 556-7.

'Dudbridge, "Pilgrimage."

${ }^{10} \mathrm{Cai}$ Yong, Du-duan, in Chen Menglei, ed., Gu-jin tu-shu ji-cheng vol. 328, (AD 1728, rpt., Tajpei: Dingwen Shuju, 1985), 63b. 
"1 "... unlimited concubines lead to disorder. Moreover, a common man is bound to have only one wife as long as the classification between the honourable and ordinary people is concerned." Ibid., $52 \mathrm{a}$.

${ }^{12}$ Liang Qichao, Zhongguo wen-hua shi, in Yin-bing-shi he-ji, vol. 10, (1936, rpt., Beijing: Zhonghua, 1989), 7; Chen Guyuan, hun-yin, 68. '3Xizhou Sheng, Xing-shi, 206.

14Ibid., 148. All translations in this paper are by the present author. islbid., 1, 4-6.

${ }^{16} \mathrm{Ibid} ., 454-61$. Tiaogeng's background is similar to that of Sun Xuee, a concubine of Ximen Qing in Jin ping mei (The Golden Lotus), who is in charge of cooking for the whole household of the Ximen family. 'Ibid., 617-23.

${ }^{19}$ Xizhou Sheng, Xing-shi, 366-8.

${ }^{19}$ Liu Shide, et al., eds., Gu-ben xiao-shuo cong-kan (GRXSCA), collection 8 (Beijing: Zhonghua, 1990), 205; Ling Mengchu, Er-ke pai-an jinggi (seventeenth century, rpt. Shanghai: Shanghai Guji, 1985), 767. ${ }^{20}$ Late Ming writer, Feng Menglong, recorded an old story in which a poor girl chooses to be a concubine of a general to improve the situation of her own family. See Feng Menglong, Zhi nang (seventeenth century, rpt., Zhengzhou: Zhongzhou Guji, 1986), 657.

"Xizhou Sheng, Xing-shi, 622-3.

22Ibid., 5-6.

${ }^{23}$ Ibid., 154. In another story of the late Ming period, a merchant purchases a concubine for three-hundred taels of silver. See Ling Mengchu, Er-ke, 768-9. Seventeenth-century writer Zhang Daj also recorded that his younger brother once bought a concubine for several taels of silver. See Zhang Dai, Lang-huan wen-ji (seventeenth century, rpt., Shanghai: Zhongguo Wenxue Zhenben Congshu, 1935), 125. ${ }^{24}$ Xizhou Sheng, Xing-shi, 148, 300-1.

${ }^{25}$ Virginity was an important concern in purchasing concubines. According to Shen Defu, some buyers might ask for refunds when their newly purchased concubines turned out not to be virgins. Those who had lost their virginity would be valued at only three tenths of the prices of virgins. See Shen Defu, Wanli ye-huo-bian (seventeenth century, rpt., Beijing: Zhonghua Shuju, 1957), 598.

${ }^{26}$ Xizhou Sheng, Xing-shi, 454-61.

27Ibid. 466-7. The above cases are from middle class gentry families located in Northern China. Cases from higher social levels or richer areas may present higher standards.

20Prices in seventeenth-century China varied from time and place. The market prices in the chart reflect those of the late Ming. For a brief reference to Ming rice prices, see Zhao Yi, Nie-er-shi zha-ji, in Cong-shu ji-cheng chu-bian (CSJCCB) (Beijing: Zhonghua, 1985), 781. Dan is a weight unit used in traditional Chinese grain exchange and 
taxation. Onc dan of rice was approximately 60 kilograms. See, Wu Chengluo, Zhongguo du-liang-heng shi (Shanghai: Shanghai Shudian, 1984), 107-12.

${ }^{29}$ Shen Defu, Ye-huo-biam, 597; Zhang Dai, Tao-an meng-yi, 45, in CSJCCB, also see Zhao Yi, Gai-yu, 852.

${ }^{30} \mathrm{Da}$ Ming lu (Ming dynasty, rpt., Shenyang, Liaoshen Shushe, 1989), 442, 444, 451; also see Yang Xuefeng, Ming-dai de shen-pan zhi-du (Taipei: Liming Wenhua Shiye Gongsi, 1981), 372.

"Dong Kang, Qiu-shen zhi-du di-yi bian, in Shen Yunlong, ed., Ming Qing shi-liao hui-bian collection 6 (Taipei: Wenhai, 1967), 9-34.

${ }^{32}$ Xizhou Sheng, Xing-shi, 784-7. Other cases of wives and concubines addressing each other "sister" can be found in Ming and Qing literature. Nevertheless, when describing a similar case, Qing scholar, Chu Renhuo, used "concubine ritually treated wife as if she were a younger sister" as a title to indicate the uniqueness of that story, which suggests that the practice was still not common. See, Chu Renhuo, Jian-bu ji, (AD 1695, rpt., in Bi-jixiao-shuo da-guan vol. 15, Yangzhou: Jiangsu Guangling Guji Keyin She, 1984), 548.

${ }^{33}$ Xizhou Sheng, Xing-shi, 302-3.

"In this chart, "by name" means personal names. In traditional China, addressing a person by personal name was not always offensive but commonly not respectful cither. In a family, people of lower status or younger generation were not supposed address people of higher status or an older generation by name. There is not evidence given in Xing-shi for how a husband or a wife might have addressed each other. In northern China it was usual to use positions instead of personal names to address each other. For example, a wife in an ordinary family might call her husband "the father of my son"; in gentry families she might call him laoye (sir).

"3ubie S. Watson and Patricia B. Ebrey, Marriage and Inequality in Chinese Society, (Berkeley and Los Angeles: University of California Press, 1991), Introduction.

${ }^{* 6}$ Xizhou Sheng, Xing-shi, 767.

${ }^{37}$ Qian Qianyi, Mu-zhai chu-xue-ji (AD 1643, rpt., Shanghai, 1985), 1991-2; for a similar case, ibid., 2036.

s'Xizhou Sheng, Xing-shi, 356-7, 426.

99Jbid., 403.

10lbid., 464-5.

"Ibid., 521.

42Ibid., 604, 607-8.

${ }^{43} \mathrm{Li}$ Qing, Zhe-yu xin-yu, (seventeenth century, rpt., Changchun: Jilin Renmin, 1987), 145-6.

${ }^{4}$ Chen Guyuan, hun-yin, 58.

${ }^{43} \mathrm{Niu} \mathrm{Xiu}, \mathrm{Hu}$ sheng $x u$-bian (AD 1700, rpt., Shanghai: Shanghai Guji, 1986), 197-8. 
${ }^{46}$ Tang Zhen, Qian Shu (seventeenth century, rpt. Beijing: Zhonghua Shuju, 1963), 165.

47lbid., 66.

${ }^{48}$ Zhang Dai, Lang-huan, 114.

${ }^{49}$ According to Zhang Mu, Gu Tinglin Xian-sheng nian-pu (Taipei: Taiwan Shangwu, 1987), Gu Yanwu married Lady Wang when he was nineteen; taking Lady Han as his concubine when he was thirtyseven, and taking Lady Dai, who was a prostitute, as his concubine four years later. The last concubine was taken when $\mathrm{Gu}$ was sixtythree. None of Gu's male children lived to adulthood.

${ }^{30} \mathrm{Chu}$ Renhuo, Jian-hu, 5.

"Niu Xiu, Hu sheng, (AD 1700, rpt., Shanghai: Shanghai Guji, 1986), 103. A similar case of rejecting a concubine can be seen in Zhou Lianggong, Shu ying (seventeenth century, spt., Shanghaj: Shanghai Guji, 1981), 127.

32Chu Renhuo, Jian-bu, 147.

${ }^{53} \mathrm{Gu}$ Yanwu, "Gui you-ren na-qic shu" (a letter to advice a friend not to take concubine), in $G u$ Tinglin shi-wen $j i$ (seventeenth century, rpt., Hongkong: Zhonghua, 1976), 143. In this letter $G u$ used the word "buy" instead of "marry" to discus concubine-taking.

"Xizhou Sheng, Xing-shi, 148.

"Fuci Jiaozhu, $C u$ bu-lu, (AD seventeenth century, rpt., in GBXSCK). 7 8. 